\title{
*УДК 657
}

Бродська I.I., к.е.н., доцент; Зеленко С.В. к.е.н., доцент Луцький національний технічний університет

\section{ОПТИМІЗАЦІЯ УПРАВЛІННЯ ДЕБІТОРСЬКОЮ ЗАБОРГОВАНІСТЮ КРЕДИТНОЇ СПІЛКИ}

Стаття присвячена розкриттю питань оптимізації управління дебіторською заборгованістю в кредитних спілках. Автором обгрунтовано класифікацію розрахунків з різними дебіторами з уточненням аналітичної інформації щодо дебіторів та оцінки заборгованості на звітну дату.

Доведено важливість формування резерву сумнівних боргів щодо іншої дебіторської заборгованості. Узагальнено основні засади формування резерву забезпечення покриття втрат від неповернутих позичок щодо дебіторської заборгованості за наданими кредитами, включаючи заборгованість за несплаченими нарахованими відсотками по кредитам. В статті уточнено ознаки простроченого кредиту.

Автором подано низку контрольних процедур задля оптимізації управління дебіторською заборгованістю небанківською фінансовою установою, зокрема: контроль за своєчасністю та повнотою платежів за різними видами дебіторської заборгованості на звітну дату (звірка планових та фактичних платежів); контроль за термінами прострочення; контроль за формуванням резервів щодо всіх видів дебіторської заборгованості.

Ключові слова: дебіторська заборгованість, дебітори, резерв сумнівних боргів, резерв забезпечення втрат від неповернутих позичок.

\section{Brodska I., Zelenko S. \\ OPTIMIZATION OF ACCOUNTS RECEIVABLE MANAGEMENT THE CREDIT UNION}

The article is devoted to the issues of optimizing the management of accounts receivable in credit unions. The author substantiates the classification of calculations with different debtors with refinement of analytical information on debtors and assessment of arrears at the reporting date.

The importance of forming a reserve of doubtful debts for other receivables is proved. The main principles of forming a provision for covering losses from undisbursed loans for accounts receivable, including debt for unpaid accrued interest on loans, are generalized. The article clarifies the features of overdue loans.

The author summarizes the information on the formation of a provision for covering losses from unsecured loans set forth in normative documents by credit unions.

\footnotetext{
* Бродська I.I., Зеленко С.В.
} 
In particular, the terms of delay, the standard of reservation and disclosure of information in the reporting on each level of delay.

It is substantiated the importance of observance of normative documents regarding the provision of provision for coverage of losses from unspent loans, as state authorities in the sphere of regulation of financial services markets are strictly controlled by the implementation of asset quality standards. The article discloses the value of the asset quality standard and describes the consequences for a non-bank financial institution for non-compliance with this indicator.

The author proves the direct relationship between the receivables and solvency of the credit union. The features of insolvency and consequences for the further activity of the institution in the event of non-fulfillment of their debt obligations are determined.

The article describes the essence and importance of prudential supervision by the National Commission for the Regulation of Financial Services Markets in order to assess the financial position of credit unions and their performance in order to minimize the risks from financial asset transactions.

The author presented a series of control procedures to optimize the management of accounts receivable by a non-bank financial institution, in particular: control over the timeliness and completeness of payments for various types of receivables at the reporting date (reconciliation of planned and actual payments); control over delays; control over the formation of reserves for all types of receivables.

Key words: accounts receivable, debtors, reserve of doubtful debts, reserve of provision for losses from unsecured loans.

\section{Бродская И.И., Зеленко С.В. \\ ОПТИМИЗАЦИЯ УПРАВЛЕНИЯ ДЕБИТОРСКОЙ ЗАДОЛЖЕННОСТЬЮ КРЕДИТНЫМ СОЮЗОМ}

Статья посвящена раскрытию вопросов оптимизации управления дебиторской задолженностью в кредитных союзах. Автором обосновано классификацию расчетов с разными дебиторами с уточнением аналитической информации по дебиторам и оценка задолженности на отчетную дату.

Доказана важность формирования резерва сомнительных долгов по прочей дебиторской задолженности. Обобщены основные принципы формирования резерва обеспечения покрытия потерь от невозвращенных ссуд по дебиторской задолженности по предоставленным кредитам, включая задолженность по неоплаченным начисленными процентами по кредитам. В статье уточнено признаки просроченного кредита.

Автором представлен ряд контрольных процедур для оптимизации управления дебиторской задолженностью небанковским финансовым учреждением, в частности: контроль за своевременностью и полнотой платежей по различным видам дебиторской задолженности на отчетную дату (сверка плановых и фактических платежей), контроль за сроками просрочки контроль за формированием резервов по всем видам дебиторской задолженности.

Ключевые слова: дебиторская задолженность, дебиторы, резерв сомнительных долгов, резерв обеспечения потерь от невозвращенных ссуд. 
Постановка проблеми у загальному вигляді та ії зв'язок 3 важливими науковими та практичними завданнями. Метою діяльності небанківських фінансових установ є задоволення потреб iii членів у взаємному кредитуванні. Проте, чим більше кредитів надається збільшується ризик їх неповернення та знижується платоспроможність, яка залежить від структури активів, капіталу та зобов'язань. На сьогоднішній день, стратегічним аспектом діяльності кредитних спілок є балансування між можливістю виконання вимог щодо своїх зобов'язань та впровадження ефективної, обгрунтованої та мінімально ризикової кредитної політики.

Нестабільність економічної ситуації на ринку фінансових послуг, зростання інфляційних процесів, підвищення плати за комунальні платежі, знецінення національної валюти призвели до зниження купівельної спроможності населення України, що збільшує попит на кредитні ресурси та, відповідно, і збільшує дебіторську заборгованість кредитних спілок.

Проблема управління дебіторською заборгованістю має пріоритетне значення, адже від ефективності цього процесу залежить ліквідність, фінансова стійкість та платоспроможність небанківських фінансових установ.

Аналіз останніх досліджень, у яких започатковано вирішення проблеми. Дослідженням проблем обліку дебіторської заборгованості займались такі науковці, як С. Голов, Ф. Бутинець, Л. Ловінська, Н. Ткаченко та інші. Дослідження різноманітних проблем функціонування кредитних спілок висвітлювались у працях: А. Понталеймоненка, В. Гончаренка, Н. Швеця, В. Клименка, С. Войцехівського та інших. Проте, дослідженню питань управління дебіторською заборгованістю саме небанківських фінансових установ не приділено достатньої уваги.

Цілі статті. Мета статті полягає в комплексному дослідженні процесу управління дебіторською заборгованістю та розробці напрямів іі оптимізації.

Виклад основного матеріалу дослідження з повним обгрунтуванням отриманих наукових результатів. Дебіторська заборгованість кредитної спілки - це сума заборгованості їі дебіторів на певну дату. Зазвичай, дебіторська заборгованість небанківських фінансових установ в Балансі відображається сукупною статтею у складі Іншої поточної дебіторської заборгованості. В цю статтю 
включаються види розрахунків 3 різними дебіторами наведені в табл. 1.

Таблиця 1

Класифікація розрахунків з різними дебіторами"

\begin{tabular}{|c|c|c|}
\hline $\begin{array}{l}\text { Вид розрахунків } \\
\text { (дебіторської } \\
\text { заборгованості) }\end{array}$ & $\begin{array}{c}\text { Аналітична } \\
\text { інформація щодо } \\
\text { дебіторів (за ознакою } \\
\text { членства в кредитній } \\
\text { спілці; без ознаки } \\
\text { членства: юридичні } \\
\text { особи / фізичні } \\
\text { особи-підприємці) }\end{array}$ & Оцінка заборгованості \\
\hline 1 & 2 & 3 \\
\hline \multirow{2}{*}{$\begin{array}{c}\text { Розрахунки } 3 \\
\text { підзвітними } \\
\text { особами }\end{array}$} & $\begin{array}{c}\text { працівники кредитної } \\
\text { спілки, які } \\
\text { придбавають } \\
\text { матеріальні цінності }\end{array}$ & \multirow{2}{*}{$\begin{array}{c}\text { заборгованість за коштами } \\
\text { наданим у відрядження } \\
\text { або підзвіт (не подано Звіт } \\
\text { про використання коштів, } \\
\text { виданих на відрядження } \\
\text { або підзвіт) на звітну дату }\end{array}$} \\
\hline & $\begin{array}{c}\text { працівники кредитної } \\
\text { спілки, які } \\
\text { перебувають у } \\
\text { відрядженні }\end{array}$ & \\
\hline $\begin{array}{c}\text { Розрахунки за } \\
\text { претензіями }\end{array}$ & $\begin{array}{c}\text { контрагенти } \\
\text { кредитної спілки: } \\
\text { юридичні та фізичні } \\
\text { особи-підприємці }\end{array}$ & $\begin{array}{c}\text { заборгованість за } \\
\text { виставленими претензіями } \\
\text { на звітну дату }\end{array}$ \\
\hline $\begin{array}{c}\text { Розрахунки за } \\
\text { кредитами } \\
\text { членам } \\
\text { кредитних спілок }\end{array}$ & $\begin{array}{l}\text { члени кредитної } \\
\text { спілки, які мають } \\
\text { діючі кредити, в т. ч.: } \\
\text { - кредити з терміном } \\
\text { погашення до трьох } \\
\text { місяців; } \\
\text { - кредити з терміном } \\
\text { погашення від } \\
\text { трьох до шести } \\
\text { місяців; } \\
\text { - кредити з терміном } \\
\text { погашення більше } \\
\text { дванадцяти місяців }\end{array}$ & $\begin{array}{c}\text { заборгованість за сумою } \\
\text { (тілом) діючого кредиту на } \\
\text { звітну дату }\end{array}$ \\
\hline
\end{tabular}


Економічні науки". - Серія "Облік і фінанси". - Випуск 15 (57). - 2018.

Продовження табл. 1

\begin{tabular}{|c|c|c|}
\hline 1 & 2 & 3 \\
\hline \multirow{5}{*}{$\begin{array}{c}\text { Розрахунки за } \\
\text { нарахованими } \\
\text { доходами } \\
\text { (відсотками) }\end{array}$} & $\begin{array}{c}\text { члени кредитної } \\
\text { спілки, які мають } \\
\text { діючі кредити }\end{array}$ & $\begin{array}{c}\text { заборгованість за } \\
\text { нарахованими відсотками } \\
\text { за діючим кредитом на } \\
\text { звітну дату }\end{array}$ \\
\hline & $\begin{array}{c}\text { кредитні спілки, які } \\
\text { мають діючі кредити }\end{array}$ & $\begin{array}{c}\text { заборгованість за } \\
\text { нарахованими відсотками } \\
\text { за діючим кредитом на } \\
\text { звітну дату } \\
\end{array}$ \\
\hline & $\begin{array}{c}\text { банківські установи, в } \\
\text { яких є діючі депозити } \\
\text { кредитної спілки }\end{array}$ & $\begin{array}{c}\text { заборгованість за } \\
\text { нарахованими відсотками } \\
\text { за діючим депозитом на } \\
\text { звітну дату }\end{array}$ \\
\hline & $\begin{array}{c}\text { об’єднані кредитні } \\
\text { спілки, в яких є діючі } \\
\text { депозити кредитної } \\
\text { спілки }\end{array}$ & $\begin{array}{c}\text { заборгованість за } \\
\text { нарахованими відсотками } \\
\text { за діючим депозитом на } \\
\text { звітну дату }\end{array}$ \\
\hline & $\begin{array}{c}\text { об’єднані кредитні } \\
\text { спілки з наявними } \\
\text { внесками кредитної } \\
\text { спілки до їх капіталу }\end{array}$ & $\begin{array}{c}\text { заборгованість за } \\
\text { нарахованими доходами за } \\
\text { діючим депозитом на } \\
\text { звітну дату }\end{array}$ \\
\hline $\begin{array}{c}\text { Розрахунки з } \\
\text { іншими } \\
\text { дебіторами }\end{array}$ & $\begin{array}{c}\text { члени кредитної } \\
\text { спілки, щодо } \\
\text { кредитних справ } \\
\text { яких, документи } \\
\text { передано до суду, } \\
\text { в т. ч.: } \\
\text { - судовий збір; } \\
\text { - авансовий платіж } \\
\text { до державної } \\
\text { виконавчої служби } \\
\end{array}$ & $\begin{array}{c}\text { заборгованість за сумою } \\
\text { (тілом) діючого кредиту } \\
\text { на звітну дату }\end{array}$ \\
\hline $\begin{array}{c}\text { Розрахунки за } \\
\text { безнадійними } \\
\text { кредитами }\end{array}$ & $\begin{array}{c}\text { члени кредитної } \\
\text { спілки, кредити яких } \\
\text { визнано } \\
\text { безнадійними }\end{array}$ & $\begin{array}{c}\text { заборгованість за сумою } \\
\text { безнадійного кредиту на } \\
\text { звітну дату }\end{array}$ \\
\hline
\end{tabular}

Джерело: побудовано автором за даними [2]. 
Проте, зазначена сума іншої дебіторської заборгованості відображається за мінусом резерву сумнівних боргів, який формується кредитною спілкою для відшкодування можливих втрат за іншими активними операціями (крім кредитних операцій) [6]. На практиці, зазначений резерв, спілки формують за заборгованістю членів кредитної спілки, щодо кредитних справ яких, документи передано до суду.

Крім того, кредитні спілки зобов'язані формувати резерв забезпечення покриття втрат від неповернутих позичок, включаючи прострочену заборгованість за нарахованими відсотками, з метою покриття втрат від неповернутих кредитів [6]. Цей резерв також віднімається від суми іншої дебіторської заборгованості.

Кредит члена кредитної спілки вважається простроченим, якщо:

- плановий платіж за кредитом не здійснено позичальником;

- плановий платіж за кредитом надійшов не в повному обсязі.

Резерв забезпечення покриття втрат від неповернутих позичок формується на залишок заборгованості за простроченими кредитами, враховуючи терміни прострочення. Залежно від термінів несплати, встановлено відсоток резервування, тому важливим є контроль за строками прострочення (табл. 2).

Однак, якщо кредитна спілка має фінансові можливості, регулятором - Національною комісією, що здійснює державне регулювання ринків фінансових послуг, дозволено формувати резерв забезпечення покриття втрат від неповернутих позичок в більшому розмірі, ніж передбачено встановленими нормативами [7, п. 5.1.9.]. Але на практиці це зустрічається рідко, оскільки відсотки резервування є досить високими.

Контроль за сформованим резервом спілкою здійснюється щомісячно, на останній день місяця.

Національною комісією, що здійснює державне регулювання ринків фінансових послуг контролюється дотримання нормативу якості активів за результатами кварталу при подачі кредитною спілкою звітних даних. 
Економічні науки". - Серія "Облік і фінанси". - Випуск 15 (57). - 2018.

Таблиця 2

Узагальнення інформації щодо формування кредитними спілками резерву забезпечення покриття втрат від неповернутих позичок наведеної у нормативних документах

\begin{tabular}{|c|c|c|c|}
\hline $\begin{array}{c}\text { Термін } \\
\text { прострочення } \\
\text { очікуваного } \\
\text { платежу }\end{array}$ & $\begin{array}{c}\text { Рівні } \\
\text { прострочення }\end{array}$ & $\begin{array}{c}\text { Норматив } \\
\text { резервування, від } \\
\text { суми } \\
\text { заборгованості на } \\
\text { звітну дату, \% }\end{array}$ & $\begin{array}{c}\text { Розкриття } \\
\text { інформації в } \\
\text { звітності }\end{array}$ \\
\hline 1 & 2 & 3 & 4 \\
\hline $\begin{array}{c}\text { Від } 31 \text { до } 90 \\
\text { днів }\end{array}$ & 1 & 0 & $\begin{array}{c}\text { Додаток } 5 \\
\text { Звітних данних } \\
020 \text { рядок графа } 3\end{array}$ \\
\hline $\begin{array}{c}\text { Від } 91 \text { до } 180 \\
\text { днів }\end{array}$ & 2 & 35 & $\begin{array}{c}\text { Додаток } 5 \\
\text { Звітних данних } \\
020 \text { рядок графа } 4\end{array}$ \\
\hline $\begin{array}{c}\text { Від } 181 \text { до } 365 \\
\text { днів }\end{array}$ & 3 & 70 & $\begin{array}{c}\text { Додаток } 5 \\
\text { Звітних данних } \\
020 \text { рядок графа } 5\end{array}$ \\
\hline $\begin{array}{c}\text { Понад } 12 \\
\text { місяців }\end{array}$ & 4 & 100 & $\begin{array}{c}\text { Додаток } 5 \\
\text { Звітних данних } \\
020 \text { рядок графа } 6\end{array}$ \\
\hline
\end{tabular}

* Джерело: побудовано автором за даними [5,6].

Цей показник характеризує заборгованість за проблемними кредитами (прострочені, неповернені, безнадійні, пролонговані), яка не перекривається сформованим резервом до загальної суми заборгованості за наданими кредитами. Недотримання установою нормативу якості активів призводить до застосування Комісією заходів впливу.

В свою чергу, платоспроможність небанківської фінансової установи напряму залежить від структури дебіторської заборгованості. Платоспроможність, означає можливість вчасного розрахунку спілкою щодо своїх зобов'язань (погашення заборгованості перед бюджетом, працівниками установи, перед своїми членами за депозитними та пайовими внесками, з нарахованими відсотками по 
них). Відповідно, не виконання установою у встановлений строк або строк, встановлений договором, вимоги члена кредитної спілки щодо погашення зобов'язань, трактується нормативними документами як прострочені зобов'язання [6]. Відповідно, першою ознакою неплатоспроможності кредитної спілки $€$ невиконання своїх забов'язань протягом 30 і більше календарних днів, після одержання вимоги щодо погашення зобов'язання та в розмірі 10 і більше відсотків від суми невиконаних вимог щодо зобов'язань із залучених внесків (вкладів) на депозитні рахунки. Другою ознакою неплатоспроможності є перевищення суми збитків кредитної спілки на 25 відсотків від суми резервного капіталу, обов'язкових пайових внесків та обов'язкових цільових внесків у додатковий капітал [6]. 3 моменту виникнення в кредитній спілці ознак неплатоспроможності їй заборонено залучати внески (вклади) на депозитні рахунки. В свою чергу, Національною комісією, що здійснює державне регулювання ринків фінансових послуг контролюється дотримання нормативу коефіцієнта платоспроможності, 3 метою мінімізації ризиків, пов'язаних із можливістю установи погашення своїх зобов'язань.

Контроль за дотриманням нормативів $є$ складовою пруденційного нагляду Національною комісією, що здійснює державне регулювання ринків фінансових послуг. Пруденційний нагляд здійснюється для оцінки фінансового стану кредитних спілок та результатів їх діяльності, задля мінімізації ризиків операцій з фінансовими активами.

Висновки. Таким чином, ефективне управління дебіторською заборгованістю небанківських фінансових установ $є$ запорукою стабільного їх функціонування на ринку фінансових послуг. Від правильності та своєчасності нарахування резервів за різними видами заборгованості залежить кінцевий результат діяльності та можливість (право) працювати в майбутньому.

Оптимізація управління дебіторською заборгованістю кредитною спілкою, на нашу думку, включає ряд контрольних процедур, зокрема:

- контроль за своєчасністю та повнотою платежів за різними видами дебіторської заборгованості на звітну дату (звірка планових та фактичних платежів); 
- контроль за термінами прострочення;

- контроль за формуванням резервів щодо всіх видів дебіторської заборгованості.

Оскільки найбільша питома вага в складі дебіторської заборгованості кредитних спілок належить заборгованості за наданими кредитами їх членам, на нашу думку, заходами щодо мінімізації ризиків неповернення коштів $є$ :

- видача кредитів лише під забезпечення (порука, гарантія, застава, заклад);

- нагадування щодо несплати позичальником боргу, в термін до 35 днів у телефонному режимі;

- надсилання листів-нагадувань, щодо несплати позичальником боргу в термін від 35 до 45 днів;

- надсилання листів-попереджень, щодо несплати позичальником боргу в термін від 45 до 55 днів;

- подача документів щодо стягнення боргу в судовому порядку, якщо попередні дії не призвели до погашення заборгованосTi.

1. Дробишева О.О., Гречка А.О. Шляхи оптимізації дебіторської заборгованості промислового підприємства з метою підвищення рівня його платоспроможності. Економічний вісник Запорізької державної інженерної академії. 2018. №2 (14). С.56-62.

2. Методичні рекомендації щодо ведення бухгалтерського обліку кредитною спілкою та об'єднаною кредитною спілкою, затверджені розпорядженням Державної комісії з регулювання ринків фінансових послуг України від 18.12.2003 р. № 171 .

3. Падій І.О. Теоретичні засади обліку формування та використання резервів на підприємстві. Облік і фінанси. 2018. № 3(81). С.69-74.

4. Положення (стандарт) бухгалтерського обліку 10 «Дебіторська заборгованість» затверджене Наказом Міністерства фінансів України від 08.10.1999 p. № 237 зі змінами та доповненнями, внесеними Наказом Міністерства фінансів України від 27.06.2013 р. № 627.

5. Порядок складання та подання звітності кредитними спілками та об'єднаними кредитними спілками до Національної комісії, що здійснює державне регулювання у сфері ринків фінансових послуг, затверджене розпорядженням Державної комісії з регулювання ринків фінансових послуг України від 25.12.2003 p. № 177 .

6. Положення про фінансові нормативи діяльності та критерії якості системи управління кредитних спілок та об'єднаних кредитних спілок, затверджене 
розпорядженням Державної комісії з регулювання ринків фінансових послуг України від 16.01.2004 р. № 7

7. Чуніхіна Т.С., Добривечір А.С. Організаційно-методичні аспекти обліку дебіторської заборгованості за міжнародними та вітчизняними стандартами обліку в системі управління підприємством. Науковий вісник Ужгородського національного університету. Серія: Міжнародні економічні відносини та світове господарство. 2018. Випуск 19, частина 1.С.123-126.

*УДК 336.71

Vavdiiuk Nataliia

Lutsk National Technical University, Ukraine

\section{ROLE OF NON-BANKS' ELECTRONIC MONEY IN MONETARY AGGREGATES M0, M1 IN EU, INDIA, SWITZERLAND, SINGAPORE}

In the economy of each state, money is exchanged in cash and cashless forms using electronic money. Electronic money replace paper money issued by the central bank and affects the money supply. In this scientific work is investigated the effect of cash replacement by electronic money of non-banking institutions on the total amount of money supply, namely, monetary aggregates M0 and M1. The assumptions about the circulation of electronic money and their impact on the banking system are formed. This will allow for such managerial decisions regarding the use of electronic money, which will carry out the functions of money and ensure their traffic.

Key words: electronic money, elasticity of M0, M1, currency-deposit ratio.

Вавдіюк Н.С.

\section{РОЛЬ НЕБАНКІВСЬКИХ ЕЛЕКТРОННИХ ГРОШЕЙ У ГРОШОВИХ АГРЕГАТАХ М0, М1 В ЄС, ІНДІї, ШВЕЙЦАРІЇ, СІНГАПУРI}

У економіці гроші обмінюються готівковими та безготівковими формами за допомогою електронних грошей. Електронні гроші замінюють паперові гроші, які випущені центральним банком, впливають на величину грошової маси. У статті досліджується ефект заміщення готівки електронними грошима, які випущені небанківськими установами на обсяг грошової маси, а саме: грошові агрегати M0 та М1. Сформовано припущення про обіг електронних грошей та їх вплив на банківську систему. Це дозволить приймати такі управлінські рішення щодо вико-

\footnotetext{
${ }^{*}$ Vavdiiuk Nataliia
} 